\title{
PERSONALITY TRAITS AND ENTREPRENEURIAL INTENTION: MEDIATING EFFECT OF EDUCATIONAL SUPPORT IN PUBLIC HIGHER EDUCATION
}

\author{
Mazlina Mamat' ${ }^{1}$, Hatinah Abu Bakar ${ }^{2}$, \\ Muhammad Faizal Samat ${ }^{3 *}$ and Mariam Setapa ${ }^{4}$ \\ ${ }^{1,2,4}$ Faculty of Business and Management, \\ Universiti Teknologi MARA Cawangan Kelantan, Malaysia \\ ${ }^{3}$ Malaysian Academy of SME \& Entrepreneurship Development (MASMED), \\ Universiti Teknologi MARA, Shah Alam, Malaysia
}

\begin{abstract}
The purpose of this paper was to examine the influence of personality traits (agreeableness, conscientious, neuroticism, openness and extraversion) on entrepreneurial intention and to assess the mediating role of educational support on the relationships between personality traits and entrepreneurial intention. A total of 1000 students at Universiti Teknologi MARA Cawangan Kelantan (UiTMCK) were randomly selected. Questionnaire was distributed to various faculties such as the Faculty of Business \& Management, Faculty of Accountancy, Faculty of Computer \& Mathematical Science, and Faculty of Information Management and Art \& Design. A total of 800 responses were collected and 753 of the responses were useable for the final analysis using the structural equation model partial least square (SEM-PLS 3.0). The findings revealed that agreeableness, conscientious, neuroticism, and extraversion have a significant influence on entrepreneurial intention but openness showed an insignificant influence. Besides, this study also found that educational support did not mediate the relationships between agreeableness, conscientious, neuroticism, openness and extraversion.
\end{abstract}

Keywords: personality traits, entrepreneurial intention, educational support

\section{$\underline{\text { ARTICLE INFO }}$}

Article History:

Received: 16 February 2021

Accepted: 4 June 2021

Published: 31 August 2021

* Corresponding Author: Muhammad Faizal Samat. E-mail: faiza1951@uitm.edu.my 


\section{INTRODUCTION}

Malaysia, which is a developing country and is moving towards Industrial Revolution (IR4.0), faces many challenges. These challenges are environmental pollution, poverty, technological advancement, unemployment among graduates and an increase in crime cases. Based on the Economic Review Report of the Ministry of Education, 2018, the unemployment rate among the people provided by the Statistics Department in 2017 showed 3.4 percent rate. The rate also recorded a three-fold increase at 10.8 percent for youths. Malay youths and educated Bumiputeras recorded the highest unemployment rate in 2017 covering 4.6 per cent. Meanwhile, youths with primary education recorded an unemployment rate of 1.9 per cent and Malays and Bumiputera who did not have any formal school education contributed 1.5 per cent (Syed Mohamad, 2019). This high unemployment rate provides an opportunity for them to venture into entrepreneurship. Malaysia continues to face high levels of youth unemployment challenges due to the skills imbalance and the basic structural gaps between education and industry systems. According to Ambank Research, Dr Anthony Das, young unemployment in Malaysia is constant at 10.8 percent which is higher than Singapore (4.6 percent), Thailand (5.9 percent), Vietnam (7.9 percent) and India (10.5 percent). As claimed by Basaruddin (2018), although in 2017, the unemployment rate was reported at 3.4 per cent, youth unemployment rates continue to rise three times higher at 10.8 per cent behind Indonesia (15.6) and China (10.8) but higher than Singapore, Thailand, Vietnam, Philippines and India. This issue leads to another agenda brought by the government and enforced by the Ministry of Education, which is enhancing the entrepreneurial elements covering all programmes offered in all higher learning institutions. All these programmes need to apply entrepreneurship values where students are trained to venture into entrepreneurship after graduation. Malaysians are encouraged to get involved in entrepreneurship and to consider entrepreneurship as a profession. As generally known, undergraduates are an important source of nascent entrepreneurship.

However, to meet this target, students should not only be exposed to entrepreneurial knowledge, but they need to possess the right personality traits to ensure that they succeed in their respective fields of business. These traits such as agreeableness, conscientious, neuroticism, openness 
to experience and extraversion would lead to an entrepreneurial intention among students. Thus, the aim of this study was to examine the influence of personality traits on entrepreneurial intention and to test whether educational support mediates the relationship between personality traits and entrepreneurial intention.

\section{LITERATURE REVIEW}

According to Bird (1988), entrepreneurial intention refers to a conscious state of mind that directs the attention of an individual to the achievement of the aim of venture development. Entrepreneurial intention is also described as the conviction, preparation, and dedication to continuous plan for the creation of a new enterprise or the creation of additional value (Thompson, 2009). Choo and Wong (2009) described entrepreneurial intention as knowledge exploration and evaluation that is beneficial for achieving the goal of business creation. Before starting with the actual company, the aim of entrepreneurship education is to have entrepreneurial intention because it determines the starting point of the formation of a new company. Entrepreneurial intention results from a personal commitment that has a huge effect on forming new projects (Choo \& Wong, 2009).

Entrepreneurial motive reflects an individual's desire to choose to be an entrepreneur as his or her profession. People with entrepreneurial ambitions are planning to take calculated risks, accumulate the capital needed and set up their own projects. Entrepreneurial purpose initiates act of entrepreneurship. Bird (1998) asserts that intent is the state of mind that directs an individual's intentions and behavior towards entrepreneurship. Liñán and Rodriguez (2004) claim that an individual's attempt to act entrepreneurially is based on his determination. Hmieleski and Corbett (2006) claim that the purpose of creating a high-growth enterprise is an entrepreneurial intention. Pruett (2012) claims that plans to pursue business ownership careers are entrepreneurial intentions.

The Big Five Personality Approach (Goldberg, 1990) is an inspiring basis for research focusing on finding personality differences among university students between entrepreneurs and non-entrepreneurs. In psychology, the major five personality traits (OCEAN: openness, 
conscientiousness, extraversion, agreeability, and neuroticism) have gained comprehensive research attention as fundamental personality characteristics. These personality traits are the subject of the present research.

Theoretical and observational evidence typically indicate that personality attributes are major predictors of the intention to become an entrepreneur (Brandstätter, 2011). Some personality characteristics influence people to behave entrepreneurially and to carry out entrepreneurial practices, including but not limited to, a strong need for accomplishment, creativity, risk-taking ability, uncertainty aversion and internal control locus (Thomas \& Mueller, 2000). Lüthje and Franke (2003) suggested that students' personality characteristics directly influence their intentions to start a new company. It is possible to categorize personality traits into two sets, such as general and specific personality characteristics. The general personality characteristics include openness to experience, neuroticism, extraversion, compatibility, awareness, i.e. the big five (McShane \& Von Glinow, 2018); while specific personality characteristics include control locus, need for accomplishment, autonomy, risk-taking, creativity and self-efficacy.

Openness Traits - Openness has cognitive frameworks that allow people who are more alert to opportunities than others to identify opportunities. New ideas or new inventions are an important part of new opportunities (Sarasvathy et al., 2005). An opportunity-seeing orientation is key to entrepreneurship (Stevenson \& Jarillo, 1990). The exploration and exploitation of possibilities is an important part of the business method (Shane \& Eckhardt, 2005). Gurol and Atsan (2006) found that the openness trait is positively correlated with entrepreneurial intention. From this point of view, the first hypothesis of the present study was:

H1: University students with a more openness trait have a higher entrepreneurial intention.

Conscientiousness - Individuals with high characteristics of conscientiousness take personal responsibility for their choices, prefer decisions involving a moderate degree of risk, avoid tedious, routine work, and are involved in a clear understanding of the outcomes of decisions (McShane \& Von Glinow, 2018). Zhao and Seibert (2006) concluded that among the big five personality traits, conscientiousness may have the 
closest connection to entrepreneurship status compared to managerial status. Therefore, the second hypothesis of the study was:

H2: University students with a more conscientiousness trait have a higher entrepreneurial intention.

Extraversion - Entrepreneurs strive to be more hopeful than nonentrepreneurs (Palich \& Bagby, 1995). Extroverts tend to be joyful, cheerful, happy, and hopeful (Goldberg, 1990). Extroverts will also foster the accomplishment of a successful leader's goals that can be found in entrepreneurs (Zadel, 2006). Howard and Howard (1995) discovered that the individuals of the entrepreneurial type could be classified as high on extraversion. On the basis of these research the present study proposed the following hypothesis:

H3: University students with a more extraversion trait have a higher entrepreneurial intention.

Agreeableness - Entrepreneurs can be cooperative, helpful, patient, cordial, friendly, trustful, and diplomatic (bright side), and they can also be described as combative, rough, bossy, demanding, dominant, manipulative, rude, and ruthless. Howard and Howard (1995) presented the category of entrepreneurs as an agreement ability rating average; thus, no direct correlation between agreeableness and entrepreneurship can be predicted. In addition, Zhao and Seibert (2006), stated that entrepreneurs scored on agreeableness lower than managers. Therefore, the present study proposed the following hypothesis:

H4: University students with a more agreeableness trait have a lower entrepreneurial intention.

Neuroticism - Goldberg's (1990) results support the potential negative relationship between neuroticism and entrepreneurship, because autonomy, freedom, and individualism appear to define emotionally stable individuals. In terms of purpose and perceived potential, Singh and De Noble (2003) found negative links between neuroticism and perceptions of self-employment (entrepreneur). Rauch and Frese (2007) also pointed out that there is a possibility of a negative relationship between the neuroticism 
factor (the reverse of emotional stability) and entrepreneurship. Most of the above research point to a negative relationship between neuroticism and entrepreneurship. Therefore, this study suggested the following hypothesis:

H5: University students with a more neuroticism trait have a lower entrepreneurial intention.

Recently, promoting entrepreneurship through university education and training has become part of Malaysia's national strategic agenda. For undergraduate students in Malaysia, subjects in entrepreneurship are compulsory. The entrepreneurship curriculum is expected to improve the entrepreneurial intentions of these students and also increase the awareness and skills of individual students. The aim of entrepreneurship can be affected by different subjective norms and resources that are regarded as obstacles to the development of new projects (Davey et al., 2011; Jones et al., 2011). It has been shown that there is a positive connection between economics and business education and the development of companies. As a result, the intensive growth in business education in the USA, had increased the number of start-ups and new projects (Drost, 2010). Entrepreneurial education has demonstrated greater entrepreneurial incentive than students without business courses (Solesvik, 2013). Subsequent research also show that entrepreneurship education can encourage graduates to become good entrepreneurs (Pickernell et al., 2011) as it raises students' entrepreneurial awareness that can encourage them to embrace entrepreneurship as a career and start new business ventures (Kirby, 2004).

Since the decision to be an entrepreneur is a product of complex mental processes, the Theory of Planned Actions (Ajzen, 1991) is most fitting to explain this obscure mental process that results in the development of a business venture. Many scholars (e.g. Fayolle \& Degeorge, 2006; Fayolle \& Gailly, 2004; Kolvereid \& Isaksen, 2006; Krueger, 2007) have taken up the Theory to shed light on the decision-making phase in the establishment of entrepreneurship. 


\section{METHODOLOGY}

This research was an exploratory study that used a questionnaire as its survey instrument for the collection of data and information. The target population was students in University Teknologi MARA Kelantan Branch (UiTMCK). A total of 753 usable responses were analyzed using the SEM-PLS 3.0. The questionnaire was distributed to various faculties such as the Faculty of Business \& Management, Faculty of Accountancy, Faculty of Computer \& Mathematical Science, and Faculty of Information Management and Art \& Design. The composition of personality traits was made up of five elements: agreeableness, conscientious, neuroticism and extraversion that were measured using the big five personality inventory (Goldberg, 1993). As for entrepreneurial intention, the measure was adopted from the study by Kolvereid (1996). Meanwhile, educational support measurement was adapted from Tucker and Selcuk (2009). The research instrument was adopted and adapted from a few selected questionnaires and measured with a 5-point Likert-scale ranging from strongly disagree to strongly agree.

\section{DATA ANALYSIS}

\section{Measurement Model}

The Measurement model was analyzed based on the PLS-SEM (Smart PLS 3.0) (Ringle, Wende, \& Becker, 2015). Assessment of the measurement model such as factor loading, composite reliability, Cronbach's alpha, average extracted variance (AVE), and discriminant validity were examined as well as heterotrait-monotrait (HTMT) as proposed by Henseler, Ringle, and Sarstedt (2015). 
Asia-Pacific Management Accounting Journal, Volume 16 Issue 2

Table 1: Measurement Model Result

\begin{tabular}{|c|c|c|c|c|c|}
\hline Construct & Item & Loading & CR & AVE $(>0.50)$ & $\begin{array}{c}\text { Cronbach Alpha } \\
(\alpha)\end{array}$ \\
\hline \multirow[t]{9}{*}{ Agreeableness } & $\mathrm{A} 1$ & 0.644 & \multirow[t]{9}{*}{0.919} & \multirow[t]{9}{*}{0.557} & \multirow[t]{9}{*}{0.901} \\
\hline & A2 & 0.746 & & & \\
\hline & $\mathrm{A} 3$ & 0.699 & & & \\
\hline & A4 & 0.744 & & & \\
\hline & A5 & 0.761 & & & \\
\hline & A6 & 0.770 & & & \\
\hline & A7 & 0.709 & & & \\
\hline & A8 & 0.811 & & & \\
\hline & A9 & 0.818 & & & \\
\hline \multirow[t]{10}{*}{ Conscientious } & C1 & 0.729 & \multirow[t]{10}{*}{0.921} & \multirow[t]{10}{*}{0.537} & \multirow[t]{10}{*}{0.904} \\
\hline & $\mathrm{C} 10$ & 0.746 & & & \\
\hline & $\mathrm{C} 2$ & 0.738 & & & \\
\hline & $\mathrm{C} 3$ & 0.748 & & & \\
\hline & $\mathrm{C} 4$ & 0.633 & & & \\
\hline & $\mathrm{C} 5$ & 0.739 & & & \\
\hline & C6 & 0.708 & & & \\
\hline & $\mathrm{C} 7$ & 0.735 & & & \\
\hline & C8 & 0.783 & & & \\
\hline & $\mathrm{C9}$ & 0.762 & & & \\
\hline \multirow[t]{8}{*}{ Neuroticism } & N1 & 0.720 & \multirow[t]{8}{*}{0.929} & \multirow[t]{8}{*}{0.621} & \multirow[t]{8}{*}{0.915} \\
\hline & N2 & 0.832 & & & \\
\hline & N3 & 0.783 & & & \\
\hline & N4 & 0.720 & & & \\
\hline & N5 & 0.722 & & & \\
\hline & N6 & 0.851 & & & \\
\hline & N7 & 0.835 & & & \\
\hline & N8 & 0.828 & & & \\
\hline
\end{tabular}




\begin{tabular}{|c|c|c|c|c|c|}
\hline Construct & Item & Loading & CR & $\operatorname{AVE}(>0.50)$ & $\begin{array}{c}\text { Cronbach Alpha } \\
(\alpha)\end{array}$ \\
\hline \multirow{7}{*}{$\begin{array}{l}\text { Openness to } \\
\text { experience }\end{array}$} & OE1 & 0.789 & \multirow[t]{7}{*}{0.893} & \multirow[t]{7}{*}{0.545} & \multirow[t]{7}{*}{0.860} \\
\hline & OE2 & 0.782 & & & \\
\hline & OE3 & 0.689 & & & \\
\hline & OE4 & 0.806 & & & \\
\hline & OE5 & 0.696 & & & \\
\hline & OE6 & 0.693 & & & \\
\hline & OE7 & 0.702 & & & \\
\hline \multirow[t]{9}{*}{ Extraversion } & E1 & 0.725 & \multirow[t]{9}{*}{0.899} & \multirow[t]{9}{*}{0.500} & \multirow[t]{9}{*}{0.872} \\
\hline & E10 & 0.639 & & & \\
\hline & E2 & 0.774 & & & \\
\hline & E3 & 0.796 & & & \\
\hline & E4 & 0.787 & & & \\
\hline & E5 & 0.722 & & & \\
\hline & E6 & 0.729 & & & \\
\hline & E7 & 0.589 & & & \\
\hline & E8 & 0.566 & & & \\
\hline \multirow{4}{*}{$\begin{array}{l}\text { Educational } \\
\text { Support }\end{array}$} & SPMRFC1 & 0.856 & \multirow[t]{4}{*}{0.957} & \multirow[t]{4}{*}{0.787} & \multirow[t]{4}{*}{0.945} \\
\hline & SPMRFC2 & 0.878 & & & \\
\hline & SPMRFC3 & 0.866 & & & \\
\hline & SPMRFC4 & 0.874 & & & \\
\hline \multirow[t]{6}{*}{$\mathrm{EI}$} & 11 & 0.770 & \multirow[t]{6}{*}{0.925} & \multirow[t]{6}{*}{0.754} & \multirow[t]{6}{*}{0.892} \\
\hline & 12 & 0.899 & & & \\
\hline & 13 & 0.915 & & & \\
\hline & 14 & 0.903 & & & \\
\hline & 15 & 0.912 & & & \\
\hline & 16 & 0.914 & & & \\
\hline
\end{tabular}

The table above shows that indicator loadings for all the items exceeded the recommended values of 0.6 (Hair, Black, Babin, \& Anderson, 2009). AVEs are in the range of 0.500 and 0.787 which are above the recommended value of 0.5 and $\mathrm{CR}$ ranged from 0.893 to 0.929 which exceeded the recommended value of 0.7 (Hair et al., 2009). 


\section{Discriminant Validity}

Henseler et al. (2015) suggested the Heterotrait-monotrait (HTMT) Ratio of Correlations as a rigorous method of achieving discriminant validity. HTMT, as a criterion which involves comparing it to a predefined threshold. Gold, Malhotra and Segars (2001) proposed that a value of 0.90 showed a lack of discriminant validity. Hence, as shown in Table 2 discriminant validity was established.

Table 2: Heterotrait- Monotrait (HTMT)

\begin{tabular}{lcccccc}
\hline & Agreeableness & Conscientinous & El & $\begin{array}{c}\text { Edu } \\
\text { Support }\end{array}$ & Neurotism $\begin{array}{c}\text { Openness to } \\
\text { experience }\end{array}$ & $\begin{array}{c}\text { Extra- } \\
\text { version }\end{array}$ \\
\hline Agreeableness & & & & & & \\
Conscientious & 0.492 & & & & & \\
El & 0.076 & 0.200 & & & & \\
Edu Support & 0.312 & 0.494 & 0.187 & & \\
Neurotism & 0.086 & 0.105 & 0.265 & 0.065 & \\
Openness to & 0.516 & 0.739 & 0.157 & 0.474 & 0.083 & \\
experience & 0.608 & 0.565 & 0.238 & 0.362 & 0.106 & 0.606 \\
extraversion & & & & &
\end{tabular}

\section{Structural Model}

Path analysis was performed to evaluate the structural model. The primary evaluation criteria for the structural model are the $\mathrm{R}^{2}$ values and the level of significance of the path coefficient (Barclay et al, 1995; Hair et al., 2011). 


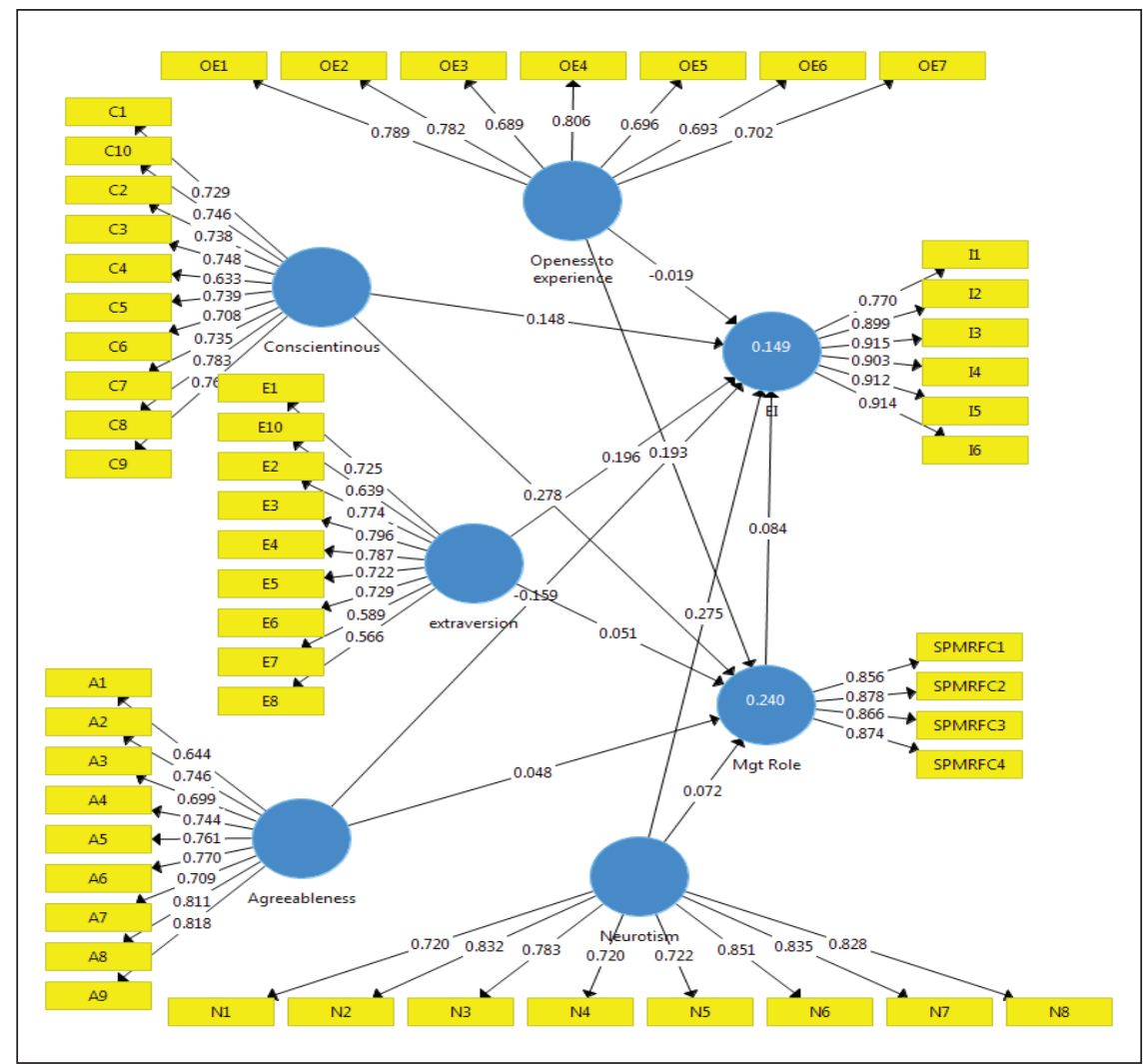

Figure 1: Structural Model

Table 3: Result of Direct Relationship

\begin{tabular}{lcccc}
\hline \multicolumn{1}{c}{ Hypothesis } & beta & t value & $\begin{array}{c}\text { P } \\
\text { values }\end{array}$ & Result \\
\hline Agreeableness -> El & -0.159 & 3.447 & 0.001 & Supported \\
Conscientious -> El & 0.148 & 2.611 & 0.009 & Supported \\
Neuroticism -> El & 0.275 & 8.392 & 0.000 & Supported \\
Openness to experience -> El & -0.019 & 0.368 & 0.713 & Not Supported \\
extraversion -> El & 0.196 & 4.570 & 0.000 & Supported \\
\hline
\end{tabular}

The $\mathrm{R}^{2}$ for entrepreneurial intention was 0.149 . Using the bootstrapping techniques with a re-sampling of 500, the path estimates and t-statistics were calculated for the hypothesized relationship. Thus, the result hypothesized 
that agreeableness, conscientious, neuroticism and extraversion had a significant relationship with entrepreneurial intention. However, openness to experience was found not significant to be related with entrepreneurial intention.

Table 4: Results of Mediating Effects

\begin{tabular}{|c|c|c|c|c|c|c|}
\hline Hypothesis & beta & $t$ value & $P$ values & LL & UL & Result \\
\hline $\begin{array}{l}\text { H4:Agreeableness } \rightarrow \text { Edu } \\
\text { Support } \rightarrow \text { Ent Intention }\end{array}$ & 0.004 & 0.772 & 0.440 & -0.003 & 0.017 & $\begin{array}{c}\text { Not } \\
\text { Supported }\end{array}$ \\
\hline $\begin{array}{l}\text { H5:Conscientinous } \rightarrow \text { Edu } \\
\text { Support } \rightarrow \text { Ent Intention }\end{array}$ & 0.023 & 1.671 & 0.095 & -0.001 & 0.054 & $\begin{array}{c}\text { Not } \\
\text { Supported }\end{array}$ \\
\hline $\begin{array}{l}\text { H6:Neuroticism } \rightarrow \text { Edu } \\
\text { Support } \rightarrow \text { Ent Intention }\end{array}$ & 0.006 & 1.348 & 0.178 & 0.000 & 0.018 & $\begin{array}{c}\text { Not } \\
\text { Supported }\end{array}$ \\
\hline $\begin{array}{l}\mathrm{H} 7: \text { Openness to } \\
\text { experience } \rightarrow \text { Edu Support } \\
\rightarrow \text { Ent Intention }\end{array}$ & 0.016 & 1.675 & 0.095 & 0.002 & 0.039 & $\begin{array}{c}\text { Not } \\
\text { Supported }\end{array}$ \\
\hline $\begin{array}{l}\text { H8:Extraversion } \rightarrow \text { Edu } \\
\text { Support } \rightarrow \text { Ent Intention }\end{array}$ & 0.004 & 0.882 & 0.378 & -0.003 & 0.017 & $\begin{array}{c}\text { Not } \\
\text { Supported }\end{array}$ \\
\hline
\end{tabular}

The results of the mediating effects are shown in Table 4. The study hypothesized that the relationship between agreeableness, conscientious, neuroticism, openness to experience and extraversion with entrepreneurial intention is not mediated by the leadership roles.

\section{DISCUSSION}

The study described the mediation effect of leadership roles among university students between agreeableness, conscientiousness, neuroticism, openness to experience, and extraversion with entrepreneurial intention. By using the Big Five Personality, findings show that agreeableness, conscientiousness, neuroticism and extraversion to significantly impact entrepreneurial intention. However, openness to experience was found to be not significant with entrepreneurial intention. Conscientiousness and extraversion were consistent with previous finding, however, agreeableness, neuroticism and openness to experience were not consistent. Agreeableness refers to the traits that focus on being cooperative, supportive, patient, cordial, pleasant, trustful, and diplomatic (bright side), while on the other side, they can be characterized as combative, harsh, bossy, demanding, dominant, manipulative, rude, and ruthless (dark side). Neuroticism refers 
to people who are more likely to be moody than normal and to experience emotions such as anxiety, fear, resentment, dissatisfaction, envy, jealousy, remorse, depressed mood, and loneliness. In this study, university students agreed that agreeableness and neuroticism were significantly related to entrepreneurial intention. In addition, openness to experience refers to the people who are open to new experiences in doing new things. In this study, university students were found not to have these traits due to the lack of opportunities.

While testing for mediation effect, educational support was found not to mediate the relationship between agreeableness, conscientiousness, neuroticism, openness to experience, and extraversion and entrepreneurial intention among university students. This is because students felt that the management of the university did not support them to have entrepreneurial intentions in many aspects.

\section{CONCLUSION}

In conclusion, this study revealed that agreeableness, conscientious, neuroticism, and extraversion have a significant influence on entrepreneurial intention among students in UiTM. It is shows that students have mixed feelings about starting a business or becoming an entrepreneur. They are more influenced by positive traits such as agreeableness, conscientious and extraversion; and also influenced by negative traits which is neuroticism. However, these all traits motivate them to become a successful entrepreneurs in the future. Besides, support from all parties especially at the university level is seen as very crucial as a platform provider and also provides the basic entrepreneurial knowledge to all students.

On the other hands, with the various assistance and incentives provided by various governments and private agencies, it is hoped that potential entrepreneurs can take advantage to start a foothold in the world of entrepreneurship. In addition, this effort is believed to help achieve the mission of the government of Malaysia to produce more entrepreneurs among students in the future. Therefore, this study is seen as very significant, especially to the University so that the mission of the University to produce graduates who are capable of becoming entrepreneurs can be realized. 


\section{Limitation and Future Research}

Despite the insightful results, the study has some limitations that need to be considered. A number of limitations were found when interpreting the results presented and conclusions drawn from this research. For UiTM in Malaysia, the results cannot be generalized widely, as the scope of the analysis is limited only to UiTM Machang. As such, care must be taken when generalizing to the entire country. This study can also be further enhanced in the future by increasing the number of sample size. In addition, this research was based on cross-sectional data. Cross-sectional data refers to data obtained by observing a variety of objects at the same time or without regard to time differences. It is limited, in other words, to shortterm observation.

For future studies, this paper has two recommendations. First, longitudinal studies focussing on long-term observations or interviews on personality characteristics and entrepreneurial intent are proposed for future researchers after a period of time to assess the accuracy of the effect. A longitudinal study is an observational research approach in which data is collected periodically over a period of time from the same subjects. Longitudinal research projects may be expanded over years or even decades, The same individuals are involved over the study period in a longitudinal cohort study (Caruana et al., 2015).

Second, according to subgroups, the scope of this research can be further expanded to evaluate what impact these groupings have on the relationships between various constructs (Ahmad, 2014). For example, to see if these classes will have some influence on the tested theories, the dataset may be divided into various groups, such as categories of students and levels of qualification. Moreover, in future studies, another mediator, such as information technology or moderators such as technological maturity, may also be added.

\section{ACKNOWLEDGEMENTS (OPTIONAL)}

The authors would like to thank Universiti Teknologi MARA Cawangan Kelantan for approving the presentation of this paper in Bandung. The 
authors would also like to convey special thanks to the Institute of Graduate Studies, Universiti Teknologi MARA Cawangan Kelantan for funding this research to be presented.

\section{REFERENCES}

Ahmad, M. F. (2014). The impact of total quality management practices with effects from moderators and mediators on business performance (Doctoral dissertation, Universiti Teknologi Malaysia).

Ajzen, I. (1991). The theory of planned behavior. Organizational Behavior and Human Decision Processes, 50, 176-211.

Barclay, D., Higgins, C., \& Thompson, R. (1995). The partial least squares (PLS) approach to causal modeling: Personal computer adoption and use as an illustration. Technology Studies, 2(2), 285-309.

Basaruddin, N. (2018, September 18). Pengangguran belia tinggi kekal cabaran utama. Berita Harian.

Bird, B. (1988). Implementing entrepreneurial ideas: The case for intention. Academy of Management Review, 13, 3, 442-453.

Brandstatter, H. (2011). Personality aspects of entrepreneurship: A look at five meta-analysis. Personality and Individual Differences, 51(3), 222-230.

Caruana, E. J., Roman, M., Hernandez-Sanchez, J., \& Solli. P. (2015). Longitudinal studies. Journal of Thoracic Disease, 7(11), 537-540.

Choo, S., \& Wong, M. (2006). Entrepreneurial intention: Triggers and barriers to new venture creation in Singapore. Singapore Management Review, 28(2), 47-64.

Davey, T., Plewa, C., \& Struwig, M. (2011). Entrepreneurship perceptions and career intentions of international student. Journal of Education and Training, 53, 335-352. 
Drost, E. A. (2010). Entrepreneurial intentions of business students in Finland: Implications for education. Advances in Management, 3(7), $28-35$.

Fayolle, A., \& DeGeorge, J. M. (2006). Attitudes, intentions, and behaviour: New approaches to evaluating entrepreneurship education. In A. Fayolle, \& H. Klandt (Eds.) International entrepreneurship education. Issues and newness (pp. 74-89). Cheltenham, UK: Edward Elgar.

Fayolle, A., \& Gailly, B. (2004). Using the theory of planned behaviour to assess entrepreneurship teaching programs: A first experimentation. IntEnt2004 Conference, Naples (Italy), 5-7 July, 2004.

Gold, A. H., Malhotra, A., \& Segars, A. H. (2001). Knowledge management: An organizational capabilities perspective. Journal of Management Information Systems, 18(1), 185-214.

Goldberg, L. R. (1990). An alternative description of personality: The big five factor structure. Journal of Personality and Social Psychology 59, $1216-1229$.

Goldberg, L. R. (1993). The structure of phenotypic personality traits. American Psychologist, 48, 26-34.

Gurol, Y., \& Atsan, N. (2006). Entrepreneurial characteristics amongst university students: Some insights for entrepreneurship education and training in Turkey. Education and Training, 48(1), 25-38.

Hair, J. F., Black, W. C., Babin, B. J., \& Anderson, R. E. (2009). Multivariate data analysis (7th ed.). New Jersey: Pearson Prentice Hall.

Hair, J. F., Ringle, C. M., \& Sarstedt, M. (2011). PLS-SEM: Indeed a silver bullet. Journal of Marketing theory and Practice, 19(2), 139-152.

Henseler, J., Ringle, C. M., \& Sarstedt, M. (2015). A new criterion for assessing discriminant validity in variance-based structural equation modeling. Journal of the Academy of Marketing Science, 43, 115-135. 
Hmieleski, K. M., \& Corbett, A. C. (2006). A study of entrepreneur improvisational behavior: Implications for performance and satisfaction. Paper presented at the Academy of Management Conference in Atlanta, $G A$.

Howard, P. J., \& Howard, J. M. (1995). The big five quickstart: An introduction to the five factor model of personality for human resource professionals. Charlotte, NC: Center for Applied Cognitive Studies.

Jones, M. V., Coviello, N., \& Tang, Y. K. (2011). International. Entrepreneurship research (1989-2009): A domain ontology and thematic analysis. Journal of Business Venturing, 26(4), 632-659.

Kirby, D. A. (2004). Entrepreneurship education: Can business schools meet the challenge? Education and Training, 46(8/9), 510-519.

Kolvereid, L. (1996). Prediction of employment status choice intentions. Entrepreneurship Theory \& Practice, 21, 47-57.

Kolvereid, L., \& Isaksen, E. (2006). New business start-up and subsequent entry into self-employment. Journal of Business Venturing, 21(6), 866-885.

Krueger, N. F. (2007). What lies beneath? The experiential essence of entrepreneurial thinking. Entrepreneurship Theory and Practice, 31(1), 123-138.

Liñán, F., \& Rodríguez, J. C. (2004). Entrepreneurial attitudes of Andalusian university students. 44th ERSA Conference, Porto (Portugal), 25-29 August, 2004.

Luthje, C., \& Franke, N. (2003). The making of an entrepreneur: Testing a model of entrepreneurial intent among engineering students at MIT. $R \& D$ Management, 33(2), 135-147.

McShane, S. L. \& Von Glinow, M. A. (2018). Organizational behavior: Emerging knowledge, global reality (8th ed.). McGraw-Hill Asia. 
Palich, L. E., \& Bagby, D. R. (1995). Using cognitive theory to explain entrepreneurial risk-taking: Challenging conventional wisdom. Journal of Business Venturing, 10, 425-438.

Pickernell, D., Packham, G., Jones, P., Miller, C., \& Thomas, B. (2011). Graduate entrepreneurs are different: They access more resources? International Journal of Entrepreneurial Behaviour and Research, 17(2), 183-202.

Pruett, M. (2012). Entrepreneurship education: Workshops and entrepreneurial intentions. Journal of Education for Business, 87, 94101.

Ramayah, T., Lee, J. W. C., \& In, J. B. C. (2011). Network collaboration and performance in the tourism sector. Service Business, 5(4), 411-428.

Rauch, A., \& Frese, M. (2007). Born to be an entrepreneur? Revisiting the personality approach to entrepreneurship. In J. R. Baum, M. Frese, \& R. A. Baron (Eds.), The psychology of entrepreneurship (pp. 41-65). Lawrence Erlbaum Associates Publishers.

Ringle, C. M., Wende, S., \& Becker, J. M. (2015). SmartPLS 3. SmartPLS $\mathrm{GmbH}$, Boenningstedt.

Sarasvathy, S. D., Dew, N., Velamuri, S. R., \& Venkataraman, S. (2003). Three views of entrepreneurial opportunity. In Z. J. Acs \& D. B. Audretsch (Eds.), Handbook of entrepreneurship research (pp. 141160). Springer, Boston, MA.

Shane, S., \& J. Eckhardt (2005). The Individual-Opportunity Nexus. In Handbook of Entrepreneurship Research: An Interdisciplinary Survey and Introduction. Eds. Z. J. Acs and D. B. Audretsch. New York, NY: Springer, 161-191.

Singh, G., \& De Noble, A. F. (2003). Views on self-employment and personality: An exploratory study. Journal of Developmental Entrepreneurship, 8(3), 265-281. 
Solesvik, M. Z. (2013). Entrepreneurial motivations and intentions: Investigating the role of education major. Education and Training, $55(3), 253-271$.

Stevenson, H. H., \& J. C. Jarillo (1990). A paradigm of entrepreneurship: Entrepreneurial management. Strategic Management Journal, 11, $17-27$.

Syed Mohamad, S. A. (2019, Feb 23). Tangani pengangguran belia Melayu. Akhbar Utusan.

Thomas, A. S., \& Mueller, S. L. (2000). A case for comparative entrepreneurship: Assessing the relevance of culture. Journal of International Business Studies, 31, 287-301.

Thompson, E. R. (2009). Individual entrepreneurial intent: Construct clarification and development of an internationally reliable metric. Entrepreneurship Theory and Practice, 33(3), 669-694.

Tucker, D., \& Selcuk, S. S. (2009). Which factors affect entrepreneurial intention of university students? Journal of European Industrial Training, 33(2), 142-159.

Zadel, A. (2006). Impact of personality and emotional intelligence on successful training in competences. Managing Global Transitions, 4(4), 363-376.

Zhao, H., \& Seibert, S. E. (2006). The big five personality dimensions and entrepreneurial status: A meta-analytical review. Journal of Applied Psychology, 91(2), 259-271. 